\title{
Farmaceutyczno-lekarska socjotopografia Poznania w okresie międzywojennym
}

\author{
Pharmaceutical-medical sociotopography of Poznan \\ in the interwar period
}

\author{
Anna Grzesiak
}

Kościan

Streszczenie: Prezentowany artykuł stanowi studium na temat zależności między rozwojem struktur społecznych a rozlokowaniem poszczególnych grup społecznych w przestrzeni geograficznej miasta Poznania w pierwszej połowie XX wieku. W badaniu uwzględniono farmaceutów i lekarzy. Podstawa studium jest analiza danych pozyskanych z ksiag adresowych, abonenckich i spisów urzędowych miasta Poznania wydanych w dwudziestoleciu międzywojennym.

\begin{abstract}
The presented article is a study on the relationship between the development of social structures and the deployment of various social groups in the geographical space of the city of Poznan in the first half of the 20th century. In this investigation pharmacists and doctors were taken into account. The primary sources for this study are address books, subscriber books, and official censuses of the city of Poznan from the interwar period.
\end{abstract}

Słowa kluczowe: medyczno-farmaceutyczna socjotopografia, Poznań, XX w., aptekarze, apteki Key words: medico-pharmaceutical sociotopography, Poznan, 20th century, pharmacists, pharmacies

\section{Wprowadzenie}

Pojęcie socjotopografii odnosi się do relacji między strukturami społecznymi a rozlokowaniem poszczególnych grup społecznych w przestrzeni geograficznej, w tym wypadku przestrzeni geograficznej miasta. Ma ona na celu przedstawić zależność między strukturami społecznymi a geografią miasta, czyli przestrzenia fizyczną ${ }^{1}$. Odtworzenie socjotopografii Poznania w odniesieniu do lekarzy i farmaceutów w dwudziestoleciu międzywojennym było możliwe dzięki analizie informacji pozyskanych z wydawanych w języku polskim ksiag adresowych oraz spisów urzędowych

* Dziękuję anonimowym recenzentom oraz prof. dr hab. Anicie Magowskiej za cenne uwagi, które pozwoliły na poszerzenie interpretacji analizowanego materiału źródłowego.

1 Ł. Filipski, Socjotopografia Torunia w okresie międzywojennym $w$ świetle analizy ksiag adresowych z 1923 i 1932 roku, „Rocznik Toruński”, 2016, s. 107. 
i abonenckich. Analizując informacje dotyczace zamieszkania lekarzy i farmaceutów, można zauważyć centralizację tych osób w Śródmieściu, które stanowiło najbardziej pożądaną dzielnicę ze względu na rozwiniętą komunikację miejska, dostęp do infrastruktury (m.in. szpitali, aptek, urzędów), działające tam instytucje kultury itp. Z czasem przedstawiciele wymienionych zawodów zaczęli zamieszkiwać także w innych dzielnicach Poznania, wybierając na swoje mieszkanie Jeżyce, Łazarz czy Wildę. Jednak zanim przejdziemy do rozważań na temat farmaceutycznej socjotopografii Poznania w okresie międzywojennym należy zapoznać się z sytuacją przestrzenno-demograficzną oraz sanitarno-zdrowotną miasta w wieku XIX oraz XX.

\section{Przemiany przestrzenno-demograficzne w XIX i pierwszych dekadach XX wieku}

Na przełomie XVIII i XIX wieku wskutek różnych klęsk elementarnych i wojen Poznań uległ dużym zniszczeniom. W tym czasie spadła także liczebność ludności miejskiej². Nie dziwi zatem, że w 1793 roku podczas włączenia Poznania do tzw. Prus Południowych zaborca zaczął myśleć o całkowitej przemianie urbanistycznej miasta. Jak podaje Andrzej Wędzki:

Dużą rolę w dalszych przeobrażeniach, zarówno w układzie przestrzennym, jak i zabudowie Poznania, odegrał katastrofalny pożar, który wybuchł 15 kwietnia 1803 roku w dzielnicy żydowskiej, gdzie było dużo budynków drewnianych i krytych łatwo palnymi materiałami. W krótkim czasie objął on znaczną część północno-wschodniej części Starego Miasta $[\ldots]^{3}$.

Aby zapobiegać takim sytuacjom, została utworzona specjalna komisja, zwana Retablissementkommission. Członkiem komisji został Ferdinand Triest, inspektor budowlany Naczelnego Dworskiego Urzędu Budowlanego w Berlinie. Główną regulacją był dokument z dnia 15 czerwca 1803 roku „Regulamin restauracyi budowli części miasta Poznania z dnia 15 IV 1803 r. pogorzałej, jako też rozszerzenie tegoż miasta"4. Zmiany dotyczyły m.in. wyznaczania nowych terenów pod zabudowę. W późniejszym czasie, czyli od 1807 roku, Poznań w wyniku zawieruchy wojennej i przekształceń politycznych został wcielony do Księstwa Warszawskiego (okres Księstwa Warszawskiego trwał w latach 1807-1815) i do 1815 roku podlegał władzy rosyjskiej. Ten burzliwy okres nie sprzyjał rozbudowie Poznania. Rozwój budownictwa był w czasach włączenia miasta do Księstwa Warszawskiego bardzo ograniczony, niemal ustał, ale już wtedy uwidoczniło się obronno-strategiczne znaczenie Poznania ${ }^{5}$. Po upadku Księstwa Warszawskiego dzięki porozumieniom Kongresu Wiedeńskiego miasto

2 A. Kaniecki, Rozwój gospodarczy Poznania, [w:] Poznań, Dzieje miasta woda pisane, Poznań 2004, s. 210.

3 J. Wędzki, Rozwój przestrzenny miasta w latach 1793-1815, [w:] Dzieje Poznania, pod red. J. Topolskiego i L. Trzeciakowskiego, Warszawa-Poznań 1994, s. 95.

4 Tamże, s. 96.

5 Tamże, s. 100-110. 
zostało stolica nowo utworzonej prowincji, tzw. Wielkiego Księstwa Poznańskiego, znowu pod panowaniem Prus ${ }^{6}$. Na rozwój przestrzenny miasta po 1815 roku miała wpływ jego lokalizacja, gdyż Poznań znajdował się niecałe 60 km od granicy rosyjskiej i z tego powodu stał się miastem garnizonowym z twierdzą.

Po odzyskaniu przez Polskę niepodległości i powrocie miasta do Rzeczypospolitej, istotnym aspektem było zorganizowanie, w 1921 roku, pierwszego Targu Poznańskiego, co przyczyniło się do kolejowego połączenia miasta z Warszawą i wzniesienia budynków targowych. W kolejnych latach skupiono się na rozwoju terenów prawobrzeżnych miasta. W 1923 roku władze wystapiły do ministerstwa z siedzibą w Warszawie z prośbą o przyłączenie 17 jednostek osadniczych znajdujących się dookoła Poznania. Można na podstawie tych decyzji stwierdzić, że władze miejskie prowadziły politykę dalekosiężna i dynamiczną. Ostatecznie wybrano tylko 7 z 17 jednostek; były to gminy: Główna, Komandoria, Rataje, Starołęka Mała, Dębiec, Winiary oraz dworski obszar Naramowic. Dzięki temu prawobrzeżne granice Poznania zostały poszerzone. Władze miejskie zapewniały mieszkańców nowo włączonych obszarów:

Będziemy się troszczyć o rozwój waszych dzielnic, [...] będziemy się starali złączyć was ściśle ze śródmieściem, jak złączono niegdyś tak samoistne gminy jak Łazarz, Jeżyce, Wildę i Górczyn, [...] w miarę środków finansowych będziemy się starali o podniesienie szkolnictwa, o zaspokojenie potrzeb ubogich $[\ldots]^{7}$.

W 1907 roku powierzchnia Poznania wynosiła 3390 ha, natomiast już w 1925 roku tereny miasta liczyły 6625 ha, przy czym 4733 ha, czyli aż 71,5\% był to obszar lewobrzeżny, a 1891 ha $(28,5 \%)$ prawobrzeżny. Wstępny projekt rozwoju przestrzennego w latach 1924-1931 był prowadzony przez Wydział Rozbudowy Miasta pod kierownictwem Sylwestra Pajzderskiego. W realizacji planu wykorzystano prace wielu wybitnych architektów. Koncentrowały się one głównie na budownictwie mieszkaniowym oraz na zapewnieniu miastu obszarów zieleni. Równie ważne było odciążenie dworca głównego od tras pociagów towarowych, przeniesienie stacji towarowej w nowe miejsce oraz uporzadkowanie linii kolejowych. Intensywne działania koncentrowały się na ułatwieniu komunikacji między lewo- i prawobrzeżną stroną Poznania, władze dążyły także do utworzenia bocznic kolejowych dla zakładów przemysłowych i fabryk. Już wtedy obywatele pragnęli oddzielić strefę przemysłową od osiedli mieszkaniowych skupiając się na aspektach zdrowotnych.

Wznoszono nowe obiekty sportowe oraz rekreacyjne np. Stadion Miejski, powstawały nowe budynki mieszkalne przy ul. Głogowskiej oraz przy ul. Roosevelta z zapleczem rozrywkowym, a więc kinem „Bałtyk”. W 1931 roku doszło do zmiany kierownika Wydziału Rozbudowy Miasta; został nim Władysław Czarnecki, który utworzył Pracownię Urbanistyczną. Opracowano w niej wiele planów i projektów.

\footnotetext{
6 M. Jaffe, Księstwo Warszawskie i konstytucja municypalna 1806-1832, [w:] Poznań pod panowaniem Pruskim, Poznań 2012, s. 123-124.

Z. Ostrowska-Kębłowska, Architektura i budownictwo w latach 1793-1815, [w:] Dzieje Poznania..., s. $102-110$.
} 
Aby poprawić jakość rozbudowy Poznania, Czarnecki zatrudnił kilku architektów, których zadaniem było w sposób właściwy zagospodarować „dzielnice urbanistycz$n^{\prime \prime}$. Na drodze do pełnego sukcesu, a zwłaszcza przekształcenia prawobrzeżnych terenów w metropolitarna dzielnicę Poznania, stanął głównie czynnik finansowy. Wszystkie inwestycje były bardzo kosztowne, wymagały zaangażowania wielu osób $\mathrm{i}$ instytucji, w tym prezydenta miasta, działającego bardzo efektywnie Towarzystwa Miłośników Miasta Poznania, architektów oraz realizatorów ich projektów. Kolejny etap rozwoju miasta został przerwany wybuchem II wojny światowej.

Podsumowując kolejne etapy rozwoju przestrzennego Poznania, można zauważyć wyraźną metamorfozę, jaką miasto przeszło w XIX i pierwszej połowie XX wieku. W XIX wieku powstania i wojny spowodowały wiele zniszczeń, a fortyfikacje i rzeka Warta stały się swoistymi granicami Poznania, powodując m.in. utrudnienia komunikacyjne. Już władze pruskie dokonały pierwszych zmian urbanistycznych i rozbudowy Poznania, daż̇ąc "do stworzenia miasta funkcjonalnego i przyjaznego człowiekowi" ${ }^{\prime \prime}$. Planiści tworząc sukcesywnie nowe dzielnice i ulice oraz rozbudowując zakłady przemysłowe, powodowali, że powstawał nowy układ urbanistyczny miasta, akceptowany przez wszystkich jego obywateli. Istotnymi hamulcami, które ograniczały modernizację urbanistyczną miasta, były jej wysokie koszty, niespokojna sytuacja polityczna, a także brak zgodności obywateli Poznania co do ostatecznego kształtu zmian.

Skupiając się na przemianach demograficznych, można zauważyć, że liczba mieszkańców Poznania wzrastała. Wiązało się to ze stwarzaniem coraz to lepszych warunków mieszkaniowych i zawodowych ludności, przede wszystkim Niemcom, a tym samym zapewnianiem możliwości awansu społecznego i wzbogacenia. Na coraz wyższym poziomie były także opieka zdrowotna i higiena miejska. Na przełomie XIX i XX wieku miasto stopniowo uwalniało się ze sztywnych fortyfikacji, rozbudowywano komunikację, pojawiały się możliwości wykupu budynku czy wzniesienia willi albo rezydencji. Pewną poprawę warunków życia niekiedy odczuła nawet biedota miejska.

Wśród mieszkańców Poznania dominowały kobiety, co mogło być związane ze spokojniejszym trybem ich życia (a tym samym możliwością dożycia późnej starości), a także z przymusowym wcielaniem mężczyzn do armii pruskiej i ich uczestnictwem w walkach zbrojnych, z których nie wszyscy wracali żywi.

\section{Sytuacja sanitarno-zdrowotna Poznania w XIX i pierwszych dekadach XX wieku}

W XIX wieku w całej Europie przeprowadzano akcje edukacyjne, które miały spowodować poprawę stanu higienicznego i warunków sanitarnych miast. Elity społeczne wspierane przez władze administracyjne, między innymi lekarze i przedstawicie-

8 M. Mrugalska-Banaszak M., Rozwój przestrzenny Poznania, [w:] Dzieje Poznania, t. 2, cz. 1, pod red. J. Topolskiego i L. Trzeciakowskiego, Warszawa-Poznań 1994, s. 817-825.

9 J. Wędzki, Rozwój przestrzenny miasta..., s. 101. 
le duchowieństwa, prowadziły agitację na rzecz schludnego wyglądu domów i ulic miast oraz codziennego stosowania mydła i wody. Czystość moralną identyfikowano z czystością fizyczną ${ }^{10}$.

Zła sytuacja sanitarno-zdrowotna Poznania w XIX wieku zwiększała umieralność mieszkańców miasta. Poznaniacy tracili życie dotknięci różnego rodzaju klęskami elementarnymi oraz głodem, brakiem dostępu do czystej wody pitnej czy wskutek niestosowania się do zaleceń higienicznych. Władze Poznania ze względu na jego lokalizację nad Wartą i Bogdanką musiały czasem sięgać po drastyczne środki. Trzeba bowiem pamiętać, że wskutek lokacji miasta w dolinie Warty aż do połowy wieku XX mieszkańcom Poznania groziły wybuchy epidemii malarii. Kolejną bardzo uciążliwa chorobą zakaźną dotykająca Poznań była cholera, której pierwsze epizody zanotowano w 1831 roku. W warunkach braku zaopatrzenia wszystkich mieszkańców w czysta wodę, zwłaszcza wśród biedoty, szerzyły się także dur brzuszny oraz czerwonka, na które najbardziej podatni byli ludzie wyniszczeni wojnami i głodem. Zła sytuacja sanitarna została opanowana dopiero pod koniec XIX wieku, gdy władze poprawiły jakość wody pitnej (m.in. poprzez założenie wodociagów) i wzrósł poziom higieny ludności ${ }^{11}$.

W pierwszej połowie XIX wieku w Poznaniu wiele kobiet umierało z powodu powikłań ciaży, porodu lub połogu. W 1848 roku wprowadzono zasady higieny i antyseptyki ${ }^{12}$, które znacząco obniżyły śmiertelność położnic ${ }^{13}$. Już w tamtych czasach zdawano sobie sprawę ze znaczenia profilaktyki, dlatego władze pruskie wprowadziły obowiązkowe szczepienia przeciw ospie i objęły nadzorem medycznym szpitale, które wcześniej pełniły funkcje przytulisk dla biedoty oraz miejsc izolacji ofiar epidemii.

$\mathrm{W}$ pierwszej połowie $\mathrm{XX}$ wieku systematycznie rosła liczba personelu medycznego (lekarzy, pielęgniarek, położnych, aptekarzy) oraz placówek medycznych. Poznań dysponował wtedy szpitalem wojskowym oraz ośmioma szpitalami cywilnymi. W 1911 roku powstał drugi w Poznaniu (pierwszy znajdował się przy dzisiejszej ulicy Libelta) szpital diakonisek przy ul. Wiktorii (współcześnie ul. Przybyszewskiego). „W 1835 roku było w mieście 26 lekarzy, czyli jeden na 1200 mieszkańców, w 1914 roku 140, czyli jeden na 1028 poznaniaków. Stawiało to Poznań na jednym z pierwszych miejsc w Rzeszy Niemieckiej"14. Kolejno powstawały szpital garnizonowy i żydowski, dziecięcy św. Józefa, sióstr miłosierdzia przy ul. Długiej, sanatorium przy ul. Łąkowej i klinika kobieca na ul. Polnej.

Na przełomie wieku XIX i XX wprowadzono ubezpieczenia zdrowotne obligatoryjne. Opieka medyczna była niezbędna ze względu na bliskość rzeki Warty, a przede wszystkim Bogdanki, która niosła nieczystości ze wsi Jeżyce. Poznaniakom często doskwierały przeziębienia, bronchit oraz malaria, a także choroby weneryczne ${ }^{15}$.

10 A. Kaniecki, Rozwój gospodarczy Poznania..., s. 488.

11 Tamże, s. 501.

12 Ojcem antyseptyki był węgierski lekarz praktykujący w Wiedniu, Ignaz Semmelweis (1818-1865), który jako pierwszy w historii nakazywał lekarzom myć ręce (w roztworze chloru) przed udaniem się do rodzącej. Za swoje poglądy został wyśmiany przez współczesnych mu lekarzy.

13 M. Kędelski, Stosunki ludnościowe w latach 1815-1918, [w:] Dzieje Poznania..., s. 262-263.

14 Tamże, s. 313.

15 Tamże, s. 314. 
Władze miasta, rozmaite bractwa, związki rzemieślnicze i prywatne fundacje kładły rosnacy nacisk na higienę poznaniaków. Warto wspomnieć, że w domach pojawiały się pierwsze łazienki, dostępne były środki czystości, tj. proszki i szczoteczki do mycia zębów, działały także łaźnie publiczne. Szybkie tempo poprawy stanu sanitarnego oraz rozwoju infrastruktury opiekuńczo-medycznej obserwowano również w dwudziestoleciu międzywojennym ${ }^{16}$.

\section{Socjotopografia zawodu lekarza i farmaceuty w Poznaniu w dwudziestoleciu międzywojennym w świetle ksiąg adresowych (ze szczególnym uwzględnieniem farmaceutów)}

Podstawę analizy stanowią dane pozyskane z ksiagg adresowych miasta Poznania za lata 1923-1939. Uzupełniaja je dane z urzędowych spisów pracowników medycznych i ksiag abonenckich, które miały charakter dopełniający do ksiagg adresowych. Ponieważ wymienione księgi obejmuja tylko wybrane lata (co wynika z faktu, że nie były wydawane co roku), analiza obejmuje rozkład przestrzenny przedstawicieli zawodów medycznych i okołomedycznych oraz wybranych instytucji świadczacych usługi medyczne w Poznaniu wyłącznie w okresach, w których księgi były wydawane. Źródłami historycznymi, które przyczyniły się do sporządzenia tego opracowania, były księgi wymienione w tabeli 1.

Na podstawie danych adresowych uzyskanych z tych ksiag przypisano przedstawicieli zawodu aptekarskiego do miejsca w przestrzeni miejskiej. Zazwyczaj przedstawiciele profesji medycznych sassiadowali ze soba, zamieszkując te same dzielnice.

Analizowane księgi adresowe z dwudziestolecia międ zywojennego zawierały takie informacje, jak: imię i nazwisko danej osoby, wykonywany zawód, charakter placówki (czy jest to instytucja prywatna, czy państwowa) oraz dokładny adres. Wszystkie wymienione $\mathrm{w}$ tabeli nr 1 księgi adresowe zostały wydane w języku polskim. Analiza ksiag z kolejnych lat pozwoliły zaobserwować, w jakim kierunku ewoluowały dzielnice Poznania ${ }^{17}$.

Wiarygodność informacji zawartych w tych księgach zależała od wielu czynników, przede wszystkim od osób odpowiedzialnych za spisywanie danych, poziomu wykształcenia tych osób i dbałości o dalsze uzupełnianie pozyskanego materiału ${ }^{18}$. Interesujący jest fakt, że tylko w najstarszych księgach adresowych miasta Poznania wymieniano dużą liczbę adresów lekarzy i aptekarzy. Działo się tak najprawdopodobniej dlatego, że funkcję informacyjna w tamtych czasach spełniała przede wszystkim prasa codzienna. To właśnie w niej w dziale ogłoszeń podawano informacje dotyczące miejsc praktykowania i jednocześnie zamieszkania aptekarzy, dentystów,

16 A. Kaniecki, Rozwój gospodarczy Poznania..., s. 560.

$17 \mathrm{Na}$ temat możliwości analitycznych, jakie daje materiał z ksiagg adresowych, zob. np. Ł. Filipski, Socjotopografia Torunia..., s. 112.

18 A. Zielińska-Nowicka, Źródła do badania zagadnień demograficznych i socjotopograficznych w XIX-wiecznym Toruniu, „Rocznik Toruński” 2008, s. 162. 
Tabela 1: Księgi adresowe miasta Poznania w dwudziestoleciu międzywojennym

\begin{tabular}{|c|c|}
\hline TYP ŹRÓDŁA & PEŁNY TYTUŁ ŹRÓDŁA \\
\hline \multirow{9}{*}{$\begin{array}{l}\text { Księga } \\
\text { adresowa } \\
\text { Poznania } \\
\text { XX w. }\end{array}$} & $\begin{array}{l}\text { Książka adresowa miasta stołecznego Poznania; Telephone directory address-book (business } \\
\text { and residential) z } 1923\end{array}$ \\
\hline & $\begin{array}{l}\text { Urzędowy spis lekarzy uprawnionych do wykonywania praktyki lekarskiej oraz aptek w Rze- } \\
\text { czypospolitej Polskiej z 1924/1925 roku }\end{array}$ \\
\hline & $\begin{array}{l}\text { Książka adresowa miasta stołecznego Poznania; Telephone directory address-book (business } \\
\text { and residential) z } 1926 \text { roku }\end{array}$ \\
\hline & $\begin{array}{l}\text { Spis abonentów sieci telefonicznej państwowej Okręgu Poznańskiej Dyrekcji Poczt } \\
\text { i Telegrafów z } 1926 \text { roku }\end{array}$ \\
\hline & $\begin{array}{l}\text { Urzędowy spis abonentów sieci telefonicznej Okręgu Dyrekcji Poczt i Telegrafów w Poznaniu } \\
\text { 1926-27 }\end{array}$ \\
\hline & Księga adresowa miasta stołecznego Poznania na rok 1933 \\
\hline & $\begin{array}{l}\text { Księga adresowa dla handlu-przemysłu-rzemiosła stoł. M. Poznania zawierająca alfabetycz- } \\
\text { ny spis adresów wszelkich przedsiębiorstw handlowych przemysłowych oraz warsztatów } \\
\text { rzemieślniczych z lat 1936/1937 }\end{array}$ \\
\hline & $\begin{array}{l}\text { Urzędowy spis: lekarzy, lekarzy-dentystów, farmaceutów, felczerów, pielęgniarek, położnych, } \\
\text { uprawnionych i samodzielnych techników dentystycznych oraz wykazy: aptek, szpitali, } \\
\text { ubezpieczalni społecznych, ośrodków zdrowia, przychodni samodzielnych oraz centrali i filii } \\
\text { Państwowej Szkoły Higieny Cz.llI. Farmaceuci, z } 1939\end{array}$ \\
\hline & Spis abonentów telefonów m. st. Poznania z uwzględnieniem branż i zawodów z roku 1939 \\
\hline
\end{tabular}

Oprac. własne na podstawie: http://www.wbc.poznan.pl/dlibra/text?id=addressbuch

lekarzy, chirurgów itp. ${ }^{19}$. Prasa codzienna była tania, natomiast zakup księgi adresowej zawsze wiązał się z poniesieniem wyższych kosztów. Jak się okazało, księgi były bardzo wybiórcze. Co istotne, nazwy placówek oraz nazwiska aptekarzy wielokrotnie pokrywały się w kolejnych latach. W księgach adresowych nie pojawiały się informacje o osobach, które odmówiły upublicznienia swoich danych. Dokładniejszym źródłem do badań socjotopograficznych okazały się spisy urzędowe przedstawicieli danego zawodu, w ich przypadku nikt nie mógł odmówić podania wymaganych informacji.

Analizując źródła, należy nadmienić, iż przed odzyskaniem niepodległości lekarze i aptekarze wybierali na swoje miejsce pracy i zamieszkania głównie Sródmieście ${ }^{20}$.

19 Zob.: M. Zdrojewska-Nowak, Produkty lecznicze i wyroby medyczne reklamowane na tamach "Gazety Toruńskiej” (1867-1921). Wybrane przykłady, „Rocznik Toruński” 2016, s. 205-224; http://yadda.icm.edu. $\mathrm{pl} /$ yadda/element/ bwmeta1.element.desklight-348da56a-e4cb-40a6-9557-e88a8a868a19?q=bwmeta1. element.cejsh-84fc94c4-6f45-4037-a321-8e1dbcda8ff9;7\&qt=CHILDREN-STATELESS (dostęp: 06.06.2018). Na podstawie pracy magisterskiej obronionej na Wydziale Farmaceutycznym UMP.

${ }_{20}$ Zob. więcej: niepublikowana praca magisterska mojego autorstwa: Farmaceutyczna socjotopografia Poznania w XIX i pierwszej połowie XX wieku, Uniwersytet Medyczny im. K. Marcinkowskiego, Poznań 2018. Praca przygotowana pod kierunkiem K. Pękackiej-Falkowskiej w Katedrze i Zakładzie Historii i Filozofii Nauk Medycznych, Wydział Lekarski I. 
Tu znajdowało się wiele wytwornych kamienic, kościołów i instytucji, a także szpital sióstr miłosierdzia i inne placówki medyczne. Ulice były ze soba połączone, a niektóre z nich, np. św. Marcin, posiadały przystanki tramwajowe, co ułatwiało dotarcie pacjentom z różnych części miasta. Dzielnica była zamieszkiwana przez zamożnych obywateli, którzy zazwyczaj byli właścicielami kamienic. Oddzielone od Śródmieścia rzeką Wartą Chwaliszewo było również dobrą lokalizacją z perspektywy lekarzy i farmaceutów. Na pozostałych obrzeżach miasta aptek było mniej, na co mogli uskarżać się mieszkańcy. Chwaliszewo było położone blisko rzeki, co zdecydowanie podnosiło ryzyko infekcji czy chorób, a więc prowadzenie apteki było uzasadnione.

„Ksiaż̇ka adresowa miasta stołecznego Poznania; Telephone directory addressbook (business and residential)" z 1923 roku pokazuje, że trend wybierania Śródmieścia jako miejsca zamieszkania i pracy wynikał z odziedziczonej po czasach pruskich lokalizacji aptek. Tę dzielnicę zamieszkiwała większość aptekarzy, którzy

Mapa 1. Miejsca zamieszkania aptekarzy w Poznaniu w 1923 roku

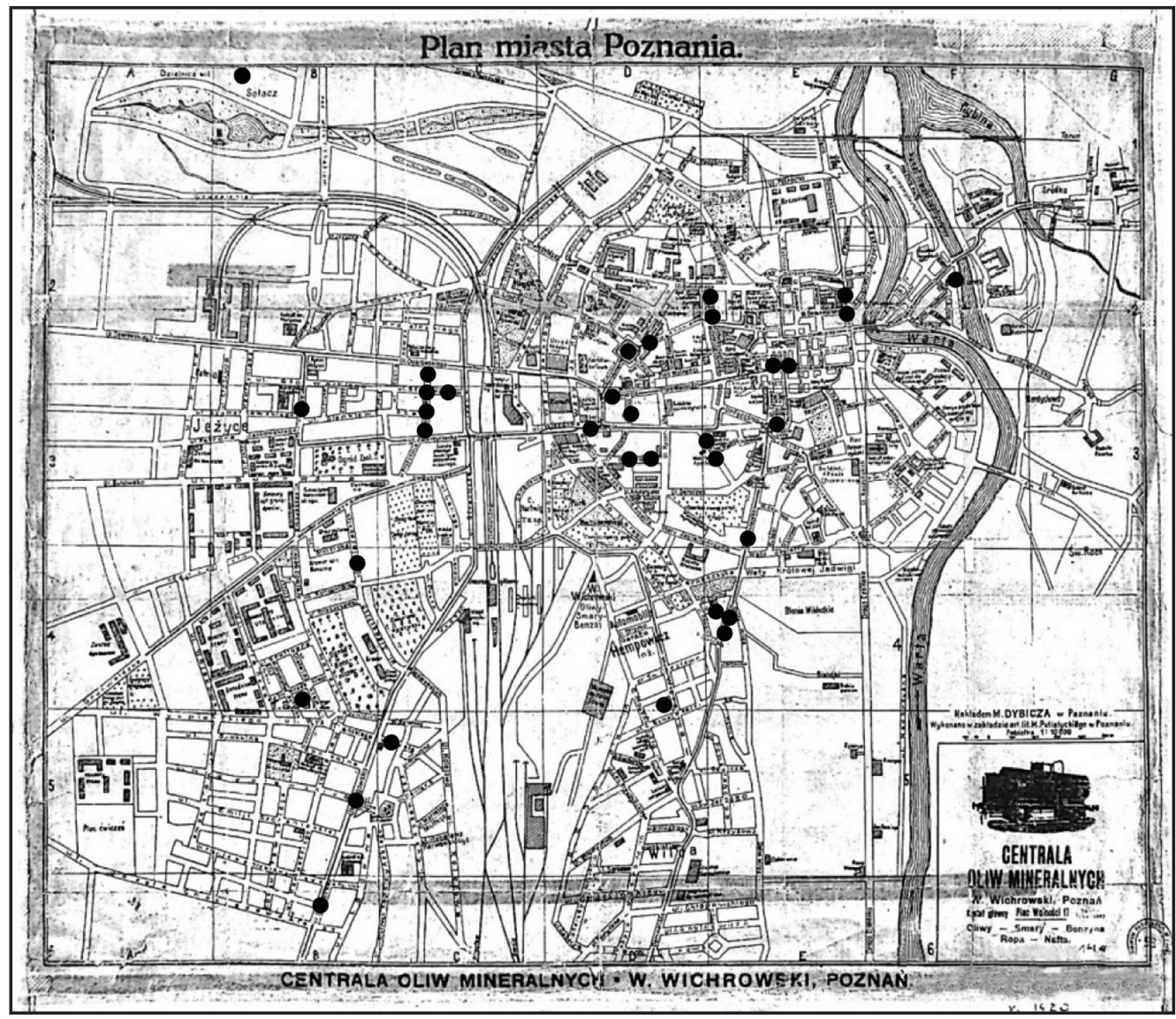

Źródło: oprac. własne na podstawie Książki adresowej miasta stołecznego Poznania; Telephone directory address-book (business and residential), Poznań 1923. 
Tabela 2. Wykaz aptekarzy wraz z miejscami pracy i zamieszkania w Poznaniu w 1923 roku

\begin{tabular}{|c|c|c|c|c|c|}
\hline Nazwisko & $\begin{array}{l}\text { Imię lub jego } \\
\text { inicjał }\end{array}$ & Określenie zawodu & Miejsce pracy & Ulica & $\begin{array}{l}\text { Nu- } \\
\text { mer } \\
\text { domu }\end{array}$ \\
\hline Altmann & Józef & $\begin{array}{l}\text { Współwłaściciel apteki } \\
\text { „Czerwonej” }\end{array}$ & $\begin{array}{l}\text { Apteka „Czerwona”, } \\
\text { Rynek } 37\end{array}$ & Mickiewicza & 24 \\
\hline Amrogowicz & Alfons & $\begin{array}{l}\text { Właściciel apteki } \\
\text { „Zielonej” }\end{array}$ & $\begin{array}{l}\text { Apteka "Zielona”, ul. } \\
\text { Wrocławska } 31\end{array}$ & Wrocławska & 31 \\
\hline Becker & Walerja & $\begin{array}{l}\text { Wdowa po aptekarzu, } \\
\text { właścicielka apteki św. } \\
\text { Marcińskiej }\end{array}$ & $\begin{array}{l}\text { Właścicielka apteki } \\
\text { przy ul. Św. Marcin } 18\end{array}$ & Św. Marcin & 18 \\
\hline Bethge & Roman & $\begin{array}{l}\text { Nabywca w } 1922 \text { r. } \\
\text { apteki św. Marcińskiej }\end{array}$ & $\begin{array}{l}\text { Apteka św. Marcińska, } \\
\text { ul. Św. Marcin } 18\end{array}$ & PI. Nowomiejski & 3 \\
\hline Bock & Fritz & $\begin{array}{l}\text { Właściciel apteki } \\
\text { "Fortuna" }\end{array}$ & $\begin{array}{l}\text { Apteka Fortuna, ul. } \\
\text { Córna Wilda } 96\end{array}$ & Górna Wilda & 96 \\
\hline Bohlen & Maksymilian & Aptekarz & & Przecznica & 5 \\
\hline Buczkowski & Stanisław & Aptekarz & & Piekary & 8 \\
\hline Cegielski & Henryk & $\begin{array}{l}\text { Właściciel apteki „Pod } \\
\text { Eskulapem” }\end{array}$ & $\begin{array}{l}\text { Apteka „Pod Esku- } \\
\text { lapem”, ul. Wielka } \\
\text { Rycerska } 13 \text { (dziś Plac } \\
\text { Wolności) }\end{array}$ & Śniadeckiego & 17 \\
\hline Ciesielski & Stanisław & Aptekarz & & Wielkie Garbary & 29 \\
\hline Czarnikau & Izydor & $\begin{array}{l}\text { Współwłaściciel apteki } \\
\text { "Czerwonej" }\end{array}$ & $\begin{array}{l}\text { Apteka „Czerwona”, } \\
\text { Rynek } 37\end{array}$ & Mickiewicza & 29 \\
\hline Dalski & Marjan & $\begin{array}{l}\text { Właściciel apteki „Pod } \\
\text { Złotym Lwem” }\end{array}$ & $\begin{array}{l}\text { Apteka "Pod Złotym } \\
\text { Lwem", Rynek } 75\end{array}$ & Stary Rynek & 75 \\
\hline Eppen & Ferdynand & $\begin{array}{l}\text { Właściciel apteki „św. } \\
\text { Piotra” }\end{array}$ & $\begin{array}{l}\text { Apteka „św. Piotra”, } \\
\text { ul. Półwiejska } 1\end{array}$ & Półwiejska & 1 \\
\hline Gertych & Józef & Aptekarz & & Łazarska & 13 \\
\hline Górski & Marcin & Aptekarz & & Skarbowa & 3 \\
\hline Holec & Mieczysław & $\begin{array}{l}\text { Właściciel apteki w } \\
\text { Stęszewie, od } 1929 \text { r. } \\
\text { dzierżawca apteki w } \\
\text { Głównej }\end{array}$ & & $\begin{array}{l}\text { Aleja Marcin- } \\
\text { kowskiego }\end{array}$ & 5 \\
\hline Klose & Fryd. & $\begin{array}{l}\text { Właściciel apteki } \\
\text { „Sapieżyńskiej” }\end{array}$ & $\begin{array}{l}\text { Apteka "Sapieżyńska”, } \\
\text { róg Placu Sapieżyń- } \\
\text { skiego i ul. Pocztowej }\end{array}$ & Pocztowa & 31 \\
\hline Koffer & Teofil & $\begin{array}{l}\text { Właściciel apteki „Św. } \\
\text { Łazarza” }\end{array}$ & Apteka „Św. Łazarza” & Strusia & 9 \\
\hline Kosicki & Wawrzyn & Aptekarz & & Słowackiego & 34 \\
\hline Laube & & Aptekarz & & Skarbowa & 4 \\
\hline Majorowicz & Antoni & $\begin{array}{l}\text { Właściciel apteki } \\
\text { „Mickiewicza" }\end{array}$ & $\begin{array}{l}\text { Apteka "Mickiewicza", } \\
\text { ul. Mickiewicza } 22\end{array}$ & Mickiewicza & 22 \\
\hline Marcinkowski & Władysław & $\begin{array}{l}\text { Właściciel apteki „Pod } \\
\text { Koroną" }\end{array}$ & $\begin{array}{l}\text { Apteka "Pod Koroną”, } \\
\text { ul. Górna Wilda } 61\end{array}$ & Górna Wilda & 61 \\
\hline Menger & Robert & $\begin{array}{l}\text { Do } 1922 \text { r. właściciel } \\
\text { apteki „Hohenzollern- } \\
\text {-Apotheke”, potem } \\
\text { znanej jako apteka } \\
\text { „Mickiewicza” }\end{array}$ & $\begin{array}{l}\text { Do } 1922 \text { r. apteka } \\
\text { znana później jako } \\
\text { „Mickiewicza” }\end{array}$ & Mickiewicza & 22 \\
\hline
\end{tabular}




\begin{tabular}{|l|l|l|l|l|c|}
\hline Michel & Karol & $\begin{array}{l}\text { Właściciel apteki } \\
\text { "Saxonia” }\end{array}$ & $\begin{array}{l}\text { Apteka "Saxonia”, ul. } \\
\text { Głogowska 74 }\end{array}$ & Chełmońskiego & 9 \\
\hline Morawski & Wacław & $\begin{array}{l}\text { Właściciel apteki „Pod } \\
\text { Gwiazdą" }\end{array}$ & $\begin{array}{l}\text { Apteka "Pod Gwiazdą", } \\
\text { ul. Kraszewskiego 12 }\end{array}$ & Kraszewskiego & 12 \\
\hline Morawski & (Wacław?) & Aptekarz & $\begin{array}{l}\text { Składnica sanitarna i } \\
\text { apteka kas chorych }\end{array}$ & $\begin{array}{l}\text { Al. Marcinkow- } \\
\text { skiego }\end{array}$ & 24 \\
\hline Szymański & Leon & $\begin{array}{l}\text { Właściciel apteki „Pod } \\
\text { Białym Orłem" }\end{array}$ & $\begin{array}{l}\text { Apteka "Pod Białym } \\
\text { Orłem”, Rynek 41 }\end{array}$ & Stary Rynek & 41 \\
\hline Walkowski & I. & $\begin{array}{l}\text { Właściciel apteki } \\
\text { "Chwaliszewskiej” }\end{array}$ & $\begin{array}{l}\text { Apteka "Chwaliszew- } \\
\text { ska”, Chwaliszewo 76 }\end{array}$ & Chwaliszewo & 76 \\
\hline
\end{tabular}

Źródło: oprac. własne na podstawie: Książka adresowa miasta stołecznego Poznania; Telephone directory address-book (business and residential), Poznań 1923; Materiały do historii aptek wielkopolskich, t. I, zestawił i opracował L. Kostrzeński, Warszawa 1929, passim.

w większości byli właścicielami koncesji na prowadzenie apteki i kamienic, w jakich były one zlokalizowane.

Aptekarze mieszkali i prowadzili apteki także na Jeżycach, Wildzie, Łazarzu i Chwaliszewie. Aptekarze mieszkali przy założonych w czasach pruskich aptekach lub takich, na które koncesje sami uzyskali.

W pierwszych latach po odzyskaniu niepodległości w każdej dzielnicy Poznania mieszkali też lekarze, którzy zwykle zamieszkiwali blisko swych miejsc pracy, szpitali lub katedr, klinik i zakładów Uniwersytetu Poznańskiego. Niektórzy uzyskiwali mieszkanie służbowe w tym samym budynku, w którym pracowali, tak jak prof. Stefan Różycki i prof. Adam Wrzosek. Niektórzy pracownicy naukowi Wydziału Lekarskiego Uniwersytetu Poznańskiego korzystali z mieszkań wynajmowanych dla nich przez uczelnię, dlatego trudno jest komentować lokalizację ich domów i mieszkań. Część lekarzy prowadziła prywatna praktykę, z którą łączyły się przede wszystkim wizyty $\mathrm{w}$ domach pacjentów. W międzywojennym Poznaniu lekarzy było prawie czterokrotnie więcej niż aptekarzy.

Księgi adresowe z lat 1926, 1933 i 1936 wymieniaja w większości tych samych aptekarzy co spis z 1923 roku oraz takie same lokalizacje aptek. Nie ma w nich za to aptekarzy niemieckich, którzy po kilku latach życia w niepodległej Polsce decydowali się na sprzedaż apteki i wyjazd do Niemiec.

Ciekawszym źródłem jest „Urzędowy spis lekarzy uprawnionych do wykonywania praktyki lekarskiej oraz aptek w Rzeczypospolitej Polskiej”21 z roku 1924/1925. W spisie wymieniono 18 aptekarzy zamieszkałych w Poznaniu, w tym 11 osób posiadajacych koncesję osobista, 2 osoby posiadające koncesję sprzedażna, 5 posiadających przywilej na prowadzenie apteki oraz aż 27 aptek. W czasach przedrozbiorowych aptekarz musiał przedstawić odpowiednie dokumenty świadczace o przygotowaniu zawodowym do prowadzenia apteki, a podstawa jej założenia mógł być jedynie dziedziczny przywilej królewski. Po zajęciu Poznania przez Prusaków podstawowym aktem prawnym

21 http:// www.wbc.poznan.pl/dlibra/docmetadata?id=102800\&from=publication 
Mapa 2. Miejsca zamieszkania lekarzy w Poznaniu w 1923 roku

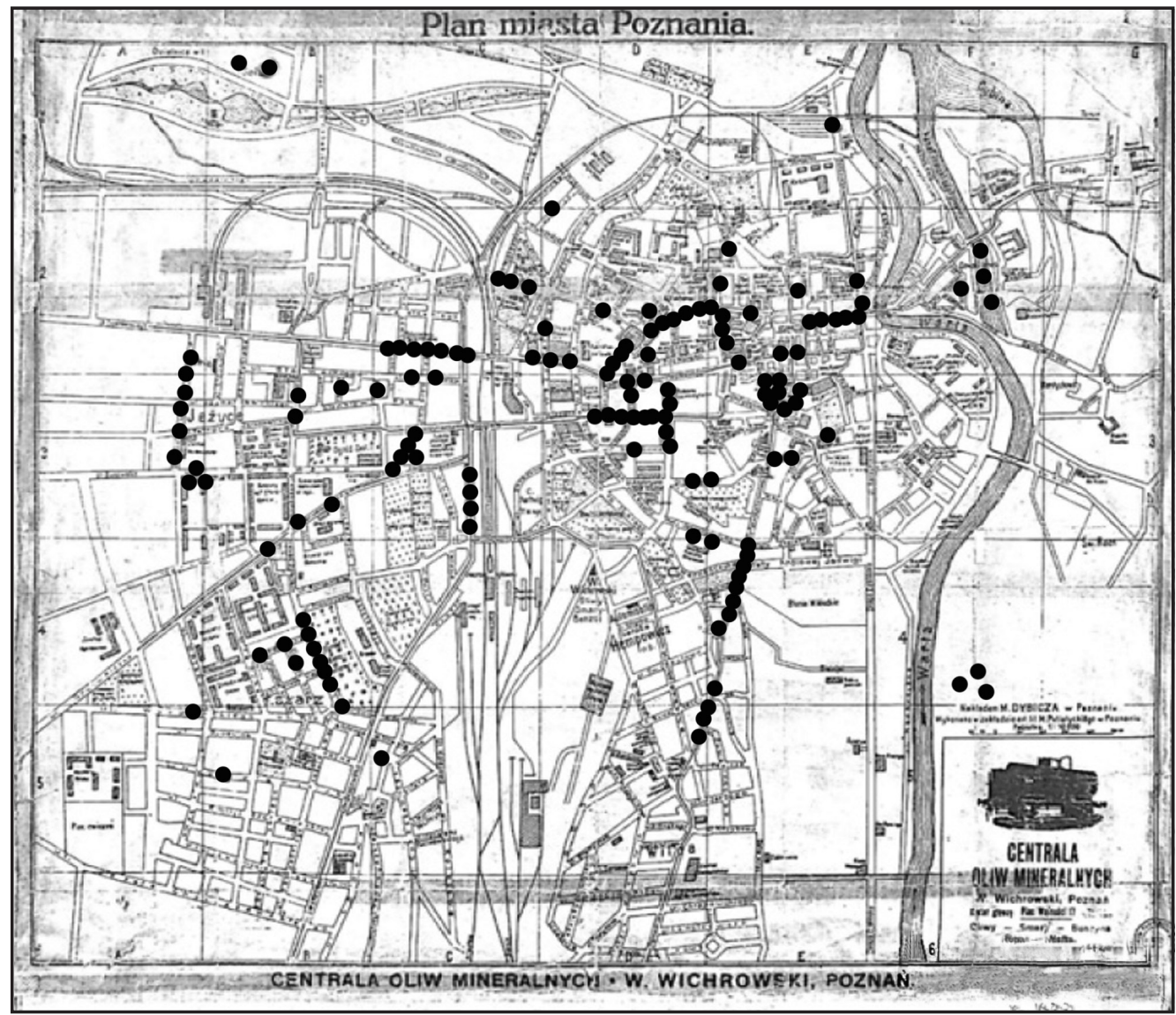

Źródło: oprac. własne na podstawie: Książka adresowa miasta stołecznego Poznania; Telephone directory address-book (business and residential), Poznań 1923.

Tabela 3. Wykaz lekarzy poznańskich wraz z ich miejscami pracy i zamieszkania w 1923 roku

\begin{tabular}{|l|l|l|l|c|}
\hline Nazwisko & \multicolumn{1}{|c|}{$\begin{array}{c}\text { Imię lub jego } \\
\text { inicjał }\end{array}$} & $\begin{array}{c}\text { Instytucja państwowa, } \\
\text { z którą związany był } \\
\text { dany lekarz }\end{array}$ & $\begin{array}{c}\text { Numer } \\
\text { domu }\end{array}$ \\
\hline Adamczewski & Ludwik & & Aleja Marcinkowskiego & 2 \\
\hline Adamczewski & Stefan & & Młyńska & 4 \\
\hline Ambrożewicz & Piotr & & Wierzbięcice & 14 \\
\hline Bajoński & Jan & $\begin{array}{l}\text { Uniwersytet Poznański, } \\
\text { Szpital Położniczy }\end{array}$ & Polna & 17 \\
\hline Bałachowski & Alfons & & Mazowiecka & 6 \\
\hline Bieszkówna & Helena & Szpital Miejski & Szkolna & $19 / 20$ \\
\hline Bochyński & Zygmunt & & Kramarska & 51 \\
\hline Bolewski & Tadeusz & & Św. Marcin & \\
\hline
\end{tabular}




\begin{tabular}{|c|c|c|c|c|}
\hline Brodniewicz & Kazimierz & & Górna Wilda & 80 \\
\hline Buxakowski & & & Wierzbięcice & 66 \\
\hline Caro & Leopold & & Masztalarska & $1 / / 2$ \\
\hline Cetkowski & Henryk & & Głogowska & 107 \\
\hline Chłapowski & Antoni & & Stary Rynek & 45 \\
\hline Chmielewski & Sew. & & Stary Rynek & 45 \\
\hline Chrzanowski & Józef & & Św. Marcin & 39 \\
\hline Ciecierski & Antoni & & Zielona & 1 \\
\hline Cobliner & & & Rzeczypospolitej & 3 \\
\hline Cohn & G. & & Pocztowa & 5 \\
\hline Dąbrowski & Stefan & $\begin{array}{l}\text { Uniwersytet Poznański, } \\
\text { Katedra Chemii Fizjolo- } \\
\text { gicznej }\end{array}$ & Grottgera & 3 \\
\hline Donat & Zygmunt & & św. Marcin & 41 \\
\hline Dziulikowska & Cecylia & & Pocztowa & 33 \\
\hline Dziulikowski & Józef & & Pocztowa & 33 \\
\hline Fechner & Maksymilian & & Górna Wilda & 61 \\
\hline Fuchs & Jan & & Przecznica & 4 \\
\hline Galewski & Mojżesz & & Wielka & 7 \\
\hline Gałdyński & Kazimierz & & Przecznica & 2 \\
\hline Gantkowski & (Paweł?) & & Dąbrowskiego & 1 \\
\hline Gesske & Franciszek & & Grunwaldzka & 49 \\
\hline Glabisz & Stefan & & Przecznica & 9 \\
\hline Gluszkines & & & Wielka & 24 \\
\hline Goroncy & Maksym. & & Tama Garbarska & 71 \\
\hline Gabler & Wacław & & Górna Wilda & 67 \\
\hline Goszke & & & Grunwaldzka & 49 \\
\hline Gościcki & Stanisław & & Przecznica & 3 \\
\hline Grabowski & Wojciech & & Św. Marcin & 6 \\
\hline Grossmann & Marja & & Ogrodowa & 16 \\
\hline Haase & Mikołaj & & Matejki & 3 \\
\hline Hanasz & Bolesław & & Pocztowa & 31 \\
\hline Holtzer & Stanisław & & Wrocławska & 30 \\
\hline Jagielski & Czesław & & Dąbrowskiego & 22 \\
\hline Jakliński & Henryk & & Fredry & 12 \\
\hline Janiszewski & & & Mielżyńskiego & $25 / 26$ \\
\hline Jarosz & Henryk & Szpital Miejski & & \\
\hline Kalitowicz & Bronisław & & Rzeczypospolitej & 7 \\
\hline Kantorowicz & Ludwik & & Mielżyńskiego & 1 \\
\hline Kapuściński & Witold & $\begin{array}{l}\text { Uniwersytet Poznański, } \\
\text { Klinika Oczna }\end{array}$ & Dąbrowskiego & 1 \\
\hline Karasiewicz & Kazimierz & & Wały Batorego & 2 \\
\hline Karwowski & Adam & $\begin{array}{l}\text { Szpital Miejski, Uniwer- } \\
\text { sytet Poznański, Klinika } \\
\text { Dermatologiczna }\end{array}$ & 27 Grudnia & 18 \\
\hline Koehler & Wilhelm & & Głogowska & 51 \\
\hline Kolszewski & Alfred & & Nowa & 3 \\
\hline
\end{tabular}




\begin{tabular}{|c|c|c|c|c|}
\hline Kołaczak & M. & & Długa & 3 \\
\hline Konkiewicz & Roman & & Wierzbięcice & $37 a$ \\
\hline Kreyn & Marcin & & Wielka & 12 \\
\hline Krzymiński & Józef & & Polna & 17 \\
\hline Kucner & Adam & & Aleje Marcinkowskiego & 17 \\
\hline Kurkiewicz Tadeusz & & $\begin{array}{l}\text { Uniwersytet Poznański, } \\
\text { Katedra Histologii i } \\
\text { Embriologii }\end{array}$ & Fredry & \\
\hline Leja & Antoni & & Słowackiego & 38 \\
\hline Lipiński & Bogdan & & Mielżyńskiego & 4 \\
\hline Łabendziński & Franciszek & $\begin{array}{l}\text { Uniwersytet Poznański, } \\
\text { Klinika Terapeutyczna }\end{array}$ & Matejki & 56 \\
\hline Markuń & & & Jasna & 5 \\
\hline Matuszewski & Romuald & & Wielkie Garbary & 40 \\
\hline Michałek & Stan. & & Polna & 17 \\
\hline Noszczyński & Stefan & & Chwaliszewo & 76 \\
\hline Nowakowski & M. & & Reya & 4 \\
\hline Parczewska & Kazimiera & & Kantaka & 2 \\
\hline Paszkiet & $\mathrm{H}$. & & Skarbowa & 14 \\
\hline Polczyński & A. & & Asnyka & 4 \\
\hline Proffa & P. & & Długa & 1 \\
\hline Rossa & Antoni & & Dąbrowskiego & 23 \\
\hline Różycki & Stefan & $\begin{array}{l}\text { Uniwersytet Poznański, } \\
\text { Katedra Anatomii }\end{array}$ & $\begin{array}{l}\text { Górna Wilda } \\
\text { (Coll. Marcinkowskiego) }\end{array}$ & 89 \\
\hline Rydlewski & Celestyn & & Szkolna & 11 \\
\hline Siebek & Narcyz & & Mickiewicza & 29 \\
\hline Skowroński & Bronisław & & św. Marcin & 25 \\
\hline Skubiszewski & Ludwik & $\begin{array}{l}\text { Uniwersytet Poznański, } \\
\text { Katedra Anatomii Pato- } \\
\text { logicznej }\end{array}$ & Szkolna & 14 \\
\hline Słoniński & Zygmunt & & Pocztowa & 28 \\
\hline Smoliński & Emil & & Górna Wilda & 29 \\
\hline Sobecki & Władysław & & Aleje Marcinkowskiego & 24 \\
\hline Sokołowska & Maria & & Chwaliszewo & 70 \\
\hline Sokołowski & Władysław & & Chwaliszewo & 70 \\
\hline Sokołowski & Lucjan & Szpital Miejski & Głogowska & 100 \\
\hline Starkowski & & & plac Działowy & 5 \\
\hline Stęszewski & Czesław & & św. Marcin & $66 / 67$ \\
\hline Sulek & Ryszard & Szpital Miejski & & \\
\hline Surzyński & Leon & & Kraszewskiego & 12 \\
\hline Szulc & Tadeusz & Szpital Miejski & Ratajczaka & 29 \\
\hline Świgoń & Walenty & & Matejki & 50 \\
\hline Tabędzki & R. & & Jasna & 5 \\
\hline Theile & Walter & & Cieszkowskiego & 4 \\
\hline Toporski & F. & & 27 Grudnia & 2 \\
\hline Ulatowski & Tadeusz & & Chełmońskiego & 2 \\
\hline Walkowski & Tadeusz & & Ratajczaka & 11 \\
\hline
\end{tabular}




\begin{tabular}{|c|c|c|c|c|}
\hline Wierusz & Antoni & & Matejki & 50 \\
\hline Wierzbicki & Romuald & & Wrocławska & $28 / 29$ \\
\hline Wilczkowski & Eugeniusz & & Górna Wilda & 29 \\
\hline Wróblewski & Kazimierz & & Matejki & 55 \\
\hline Wrzosek & Adam & $\begin{array}{l}\text { Uniwersytet Poznański, } \\
\text { Katedra Historii i Filo- } \\
\text { zofii Medycyny, Zakład } \\
\text { Antropologii }\end{array}$ & Sołacz & \\
\hline Zaremba & Gustaw & & Grottgera & 3 \\
\hline Zieliński & Stanisław & & Polna & 17 \\
\hline Ziółkowski & Czesław & & Aleje Marcinkowskiego & 21 \\
\hline Ziółkowski & Maksymilian & & Niegolewskich & 4 \\
\hline Znaniecki & Leon & & Wyspiańskiego & 6 \\
\hline Żniniewicz & Janina & $\begin{array}{l}\text { Zakład Wodolecznictwa } \\
\text { dr. Jana Żniniewicza }\end{array}$ & 3 Маја & 2 \\
\hline Żuralski & Tadeusz & $\begin{array}{l}\text { Uniwersytet Poznański, } \\
\text { Klinika Położnicza }\end{array}$ & Polna & 20 \\
\hline
\end{tabular}

Źródło: oprac. własne na podstawie: Książka adresowa miasta stołecznego Poznania; Telephone directory address-book (business and residential), Poznań 1923.

upoważniającym do prowadzenia apteki stała się koncesja osobista lub sprzedażna, czyli taka, która mogła być sprzedawana uprawnionemu aptekarzowi wraz z apteka. Po 1894 roku były wydawane koncesje osobiste, które wykluczały dziedziczenie i dobrowolne sprzedawanie aptek, a posiadacz apteki i koncesji nie miał wpływu na wybór następcy, ponieważ otrzymywał je w drodze konkursu. O pierwszeństwie w uzyskaniu koncesji w czasach pruskich decydowało nie tylko wykształcenie, ale i zasługi polityczne. Prawo pruskie obowiązywało przez prawie całe dwudziestolecie międzywojenne.

W kolejnych latach aptekarze nadal mieszkali przede wszystkim przy ul. św. Marcin, Starym Rynku czy placu Wolności. „Urzędowy spis abonentów sieci telefonicznej Okręgu Dyrekcji Poczt i Telegrafów w Poznaniu z 1926/27 roku" wymienia 12 aptekarzy posiadających telefon.

Ciekawym i ważnym źródłem do badań socjotopograficznych jest również „Urzędowy spis: lekarzy, lekarzy-dentystów, farmaceutów, felczerów, pieleggniarek, położnych, uprawnionych i samodzielnych techników dentystycznych oraz wykazy: aptek, szpitali, ubezpieczalni społecznych, ośrodków zdrowia, przychodni samodzielnych oraz centrali i filii Państwowej Szkoły Higieny" wydany w przeddzień wybuchu II wojny światowej. W części trzeciej, zatytułowanej „Farmaceuci”22, wymieniono aż 103 osoby. Do tak znaczącego zwiększenia liczby farmaceutów przyczynił się rozwój działalności dydaktycznej Oddziału Farmaceutycznego Wydziału Matematyczno-Przyrodniczego Uniwersytetu Poznańskiego ${ }^{23}$.

22 http:/ / www.wbc.poznan.pl/ dlibra/ docmetadata?id=101293\&from=publication

23 P. Skalski, K. Pękacka-Falkowska, Poznańscy studenci farmacji w latach 1920-1939: studium z zakresu historii społecznej, „Analecta: studia i materiały z dziejów nauki” 2016, nr 2 s. 139-195. 
Wykres 1. Aptekarze poznańscy wymienieni w „Urzędowym spisie lekarzy uprawnionych do wykonywania praktyki lekarskiej oraz aptek w Rzeczypospolitej Polskiej" z 1924/1925 roku według typu apteki

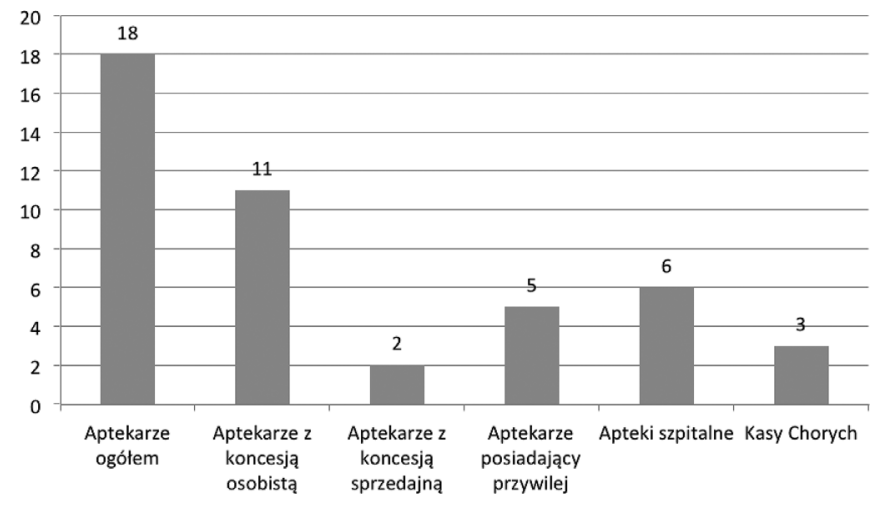

Mapa 3. Aptekarze posiadający telefon w Poznaniu w 1926 roku

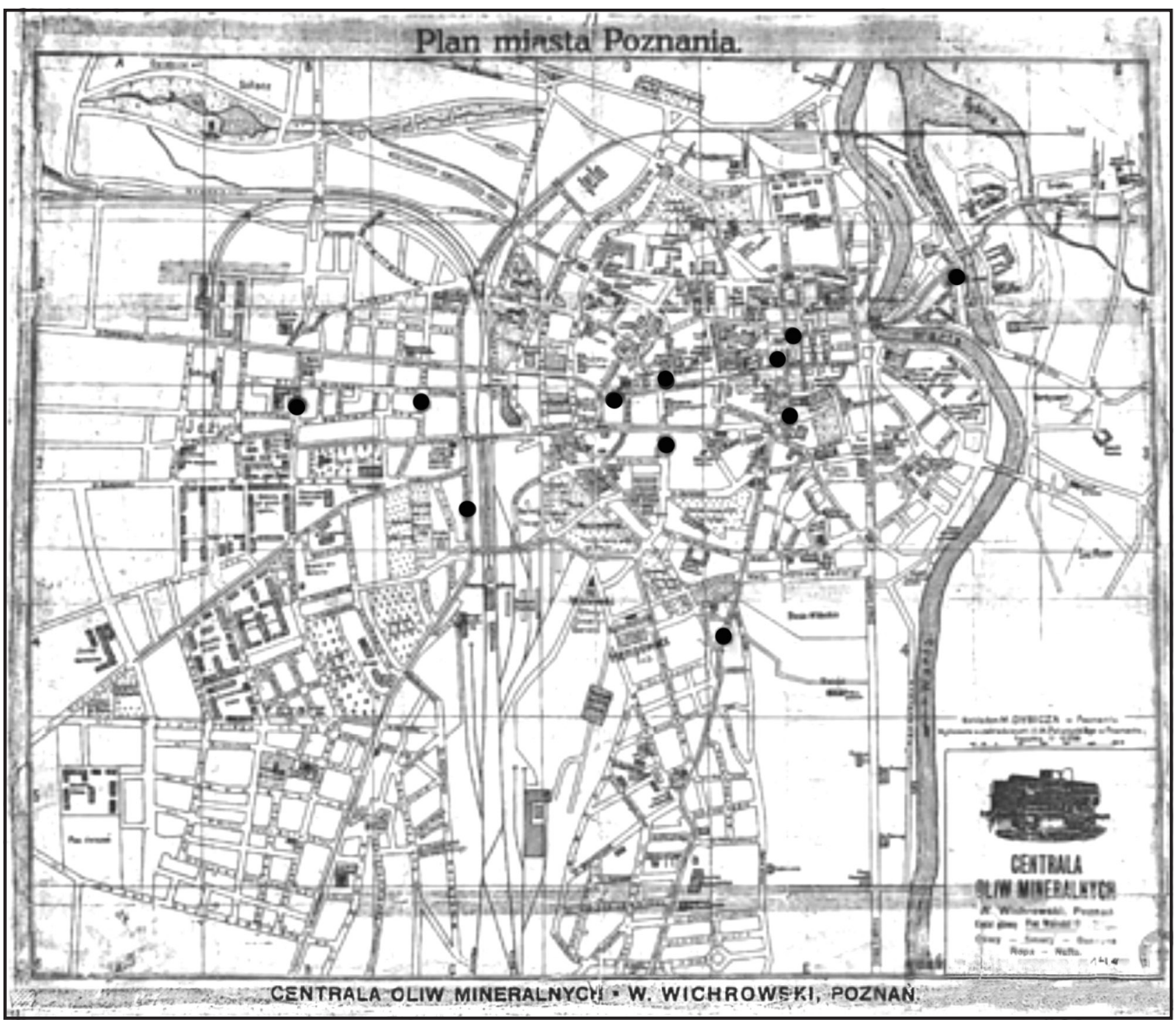

Źródło: oprac. własne na podstawie: Urzędowy spis abonentów sieci telefonicznej Okręgu Dyrekcji Poczt i Telegrafów w Poznaniu 1926-27, Poznań 1926. 
Przed wybuchem II wojny światowej farmaceuci mieszkali przede wszystkim przy ul. Ratajczaka, placu Wolności, Alei Karola Marcinkowskiego, Dabrowskiego i Focha. Najwięcej z nich, bo aż 43 osoby, zamieszkiwało na terenie Śródmieścia. Byli to nie tylko aptekarze, ale także inspektorzy farmaceutyczni, jak Alfred Reysner, pracownicy zakładów przemysłowych, jak Rafał Adamski, czy też pracownicy naukowi Uniwersytetu Poznańskiego, jak Jerzy Tułecki. Aż 21 farmaceutów zamieszkiwało na Łazarzu, 19 na Jeżycach, 3 na Chwaliszewie 24 . Można zauważyć, że wśród farmaceutów pojawiły się stosunkowo liczne kobiety ${ }^{25}$.

Mapa 4. Aptekarze w Poznaniu w 1939 roku

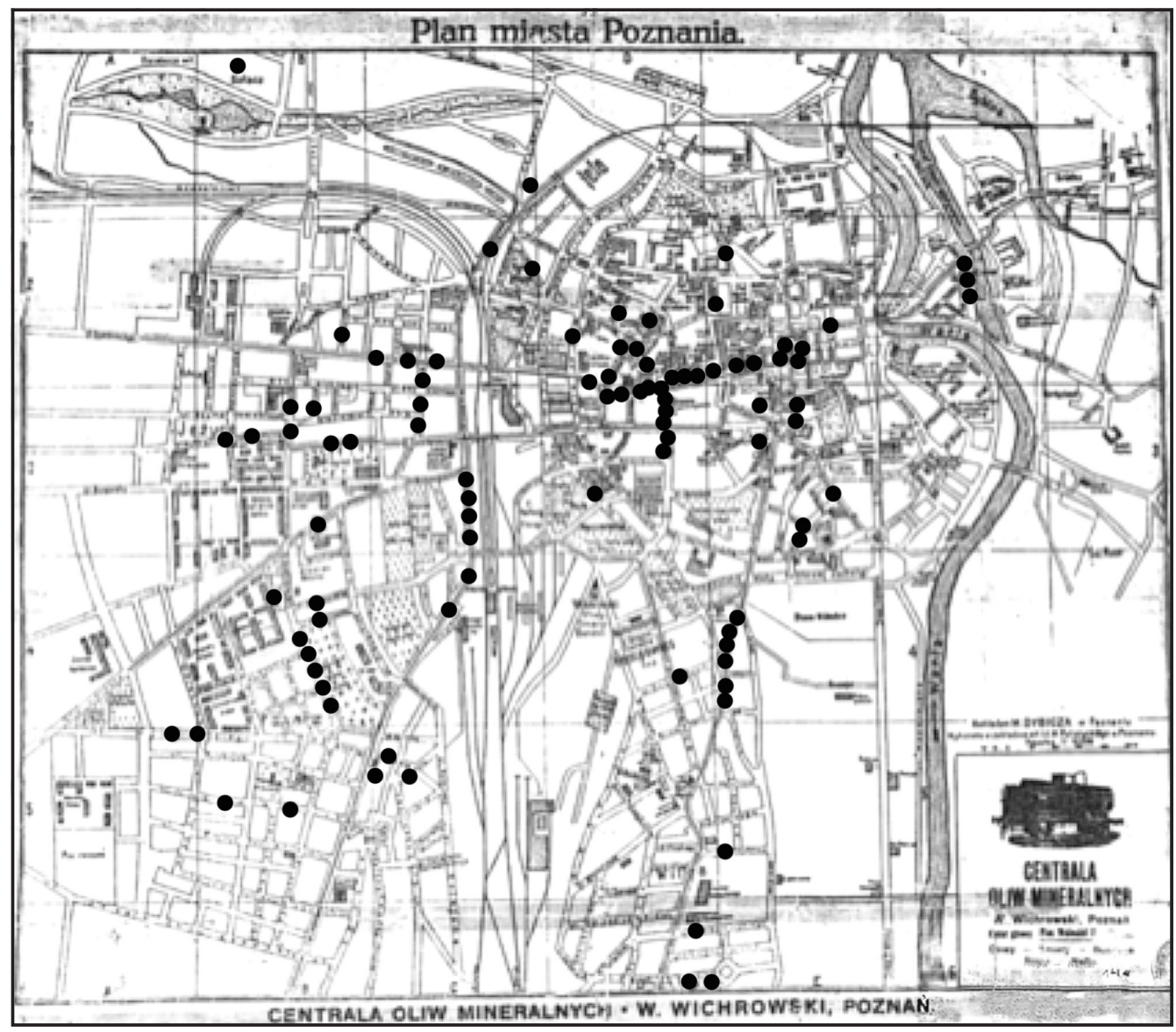

Źródło: oprac. własne na podstawie: „Urzędowy spis: lekarzy, lekarzy-dentystów, farmaceutów, felczerów, pielęgniarek, położnych, uprawnionych i samodzielnych techników dentystycznych oraz wykazy: aptek, szpitali, ubezpieczalni społecznych, ośrodków zdrowia, przychodni samodzielnych oraz centrali i filii Państwowej Szkoły Higieny", Poznań 1939.

24 http://www.wbc.poznan.pl/dlibra/

25 Zob. P. Skalski, K. Pękacka-Falkowska, Poznańscy studenci... 
Tabela 4: Wykaz farmaceutów w Poznaniu w 1939 roku

\begin{tabular}{|c|c|c|c|}
\hline Nazwisko & Imię & Ulica & $\begin{array}{c}\text { Numer } \\
\text { domu }\end{array}$ \\
\hline Adamski & Rafał & Grunwaldzka & 18 \\
\hline Amrogowicz & Alfons & Wrocławska & 31 \\
\hline Biniecki & Stanisław & 27 Grudnia & 18 \\
\hline Błaszczyk & Stanisław & Focha & $47 a$ \\
\hline Borowski & Władysław & Chwaliszewo & 76 \\
\hline Buczkowski & Stanisław & Aleje Marcinkowskiego & 10 \\
\hline Budnikowski & Bogdan & Główna & 31 \\
\hline Busza & Władysław & Kręta & 7 \\
\hline Cegielski & Henryk & plac Wolności & 13 \\
\hline Chrzan & Zbigniew & Górna Wilda & 61 \\
\hline Chwojka & Stanisław & Stary Rynek & 75 \\
\hline Cieślawski & Tadeusz & 27 Grudnia & 18 \\
\hline Czechanowski & Janusz & Focha & 125 \\
\hline Dąbrowska & Maria & plac Wolności & 12 \\
\hline Dalski & Bogdan Józef & Mickiewicza & 24 \\
\hline Dąbrowski & Tomasz & plac Wolności & 12 \\
\hline Denizot & Alfred & 3 Maja & 3 \\
\hline Dobrzyńska-Kamrowska & Janina & Bazar & \\
\hline Drecki & Konrad & Górna Wilda & 12 \\
\hline Dzierzgowski & Władysław & Focha & 147 \\
\hline Fabianowska & Bronisława Ida & Wrocławska & 31 \\
\hline Fibak & Leonard & Mylna & 15 \\
\hline Florczak & Szczepan & Działyńskich & 9 \\
\hline Gańcza & Tadeusz & Łąkowa & 8 \\
\hline Gawroński & Józef & plac Sapieżyński & $2 a$ \\
\hline Gawrychowa & Halina & plac Jackowskiego & 15 \\
\hline Gerdena & Stefan & Aleje Pułaskiego & 18 \\
\hline Głowacki & Antoni & Matejki & 51 \\
\hline Głowacki & Witold & Mickiewicza & 13 \\
\hline Grobelny & Mieczysław & Focha & 39 \\
\hline Grodnicki & Józef Tacjan & Mielżyńskiego & 21 \\
\hline Hanelt & Józef & Górna Wilda & 61 \\
\hline Hoffmann & Tadeusz & Niegolewskich & $22 \mathrm{a}$ \\
\hline Hołoga & Halina & Stroma & 26 \\
\hline Hubertowa & Józefa & Czesława & $19 a$ \\
\hline Jeske & Józef & Stary Rynek & 41 \\
\hline Karbowski & Kazimierz Józef & Szymańskiego & 3 \\
\hline Karpińska-Wiśniewska & Maria & Focha & 153 \\
\hline Karpiński & Władysław & Niegolewskich & 19 \\
\hline Kierzyński & Leon & Piłsudzkiego & 4 \\
\hline Knobelsdorf & Karol & Górna Wilda & 3 \\
\hline Kowalczyk & Stefan & Górna Wilda & 61 \\
\hline
\end{tabular}




\begin{tabular}{|c|c|c|c|}
\hline Kowalski & Kazimierz & Szwajcarska & 11 \\
\hline Kozłowska & Irena Maria & 27 Grudnia & 18 \\
\hline Kruszewski & Mieczysław & Wielka & 7 \\
\hline Kucharska & Sabina & Bluszczowa & 1 \\
\hline Kulesza & Piotr & Krzyżowa & 3 \\
\hline Lafasówna & Wanda & Gajowa & 4 \\
\hline Lesińska & Zofia & Szamotulska & 22 \\
\hline Linkowski & Michał Jerzy & Wyspiańskiego & 21 \\
\hline Litkowska & Janina & Wały Zygmunta Starego & $10 \mathrm{a}$ \\
\hline Lubierska & Felicja & Matejki & \\
\hline Łowicki & Lechosław & Fredry & 2 \\
\hline Łukaszczyk & Alfons & Orzeszkowej & 10 \\
\hline Maciejewska & Irena & Mickiewicza & 22 \\
\hline Maćkowiakówna & Krystyna & Gajowa & 1 \\
\hline Marcinkowski & Czesław & Małeckiego & 53 \\
\hline Marcinkowski & Władysław & Górna Wilda & 61 \\
\hline Michalak & Józef Stanisław & Starołęcka & 83 \\
\hline Mindowiczówna & Danuta & Plac św. Krzyski & \\
\hline Miklaszewska & Maria & Skryta & 10 \\
\hline Milewski & Ludwik & plac Sapieżyński & \\
\hline Milewski & Marian & Matejki & 57 \\
\hline Morawski & Czesław & Kraszewskiego & 12 \\
\hline Morawski & Wacław & Kraszewskiego & 12 \\
\hline Narzyński & Henryk Leon & Młyńska & 2 \\
\hline Nietupski & Julian & Wały Jana III & 7 \\
\hline Nowaczyński & Stefan Ludwik & Ratajczaka & 27 \\
\hline Nyklewicz & Marian & Ratajczaka & 28 \\
\hline Nyklewiczowa & Janina & Ratajczaka & 28 \\
\hline Okopiński & Tadeusz & Wyspiańskiego & 12 \\
\hline Olszak & Florentyna & Łąkowa & $1 / 2$ \\
\hline Ostrowicz & Stefan & Stary Rynek & 37 \\
\hline Pasierbińska & Maria & Graniczna & 15 \\
\hline Petrykowska & Janina & Konopnickiej & 22 \\
\hline Pniewska & Gertruda & plac Wolności & 13 \\
\hline Pyszkowski & Wojciech & Główna & 53 \\
\hline Reysner & Alfred & plac Jackowskiego & 52 \\
\hline Rogala & Jan & Strusia & 9 \\
\hline Schreiberowa & Eleonora & plac Działowy & 7 \\
\hline Skarżyński & Kazimierz & Aleja Szopena & 8 \\
\hline Skarżyński & Wojciech & Chłapowskiego & 2 \\
\hline Skubiówna & Janina & Ratajczaka & 12 \\
\hline Sławek & Władysława & Bazar & \\
\hline Sławkówna & Władysława & Bazar & \\
\hline Smigajówna & Maria & Focha & 47 \\
\hline Stachowiak & Marian & 27 Grudnia & 18 \\
\hline
\end{tabular}




\begin{tabular}{|l|l|l|c|}
\hline Stockówna & Janina & Dąbrowskiego & 76 \\
\hline Sysiakówna & $\begin{array}{l}\text { Stanisława Wan- } \\
\text { da }\end{array}$ & Stary Rynek & 75 \\
\hline Szulc & Bogdan & Matejki & 1 \\
\hline Szymanowicz & Stefan & Dąbrowskiego & 76 \\
\hline Szymański & Jerzy Florian & 27 Grudnia & 18 \\
\hline Tułecki & Jerzy & Chwaliszewo & \\
\hline Tuszyński & Antoni & Dąbrowskiego & 5 \\
\hline Urbański & Eugeniusz & Prusa & 5 \\
\hline Walkowski & Jerzy & Chwaliszewo & 76 \\
\hline Wawrzyniak & Jan & Strzelecka & 25 \\
\hline Wawrzyniakówna & Helena & Jasna & 5 \\
\hline Wener & Stanisław & Raczyńskich & 11 \\
\hline Wilczewski & Władysław & Mazowiecka & 12 \\
\hline Winkler & Józef Aleksander & Matejki & 39 \\
\hline Wysocki & Józef & Ratajczaka & 12 \\
\hline Ziętarska & Władysława & Dębiecka & 6 \\
\hline
\end{tabular}

Źródło: oprac. własne na podstawie: Urzędowy spis: lekarzy, lekarzy-dentystów, farmaceutów, felczerów, pielęgniarek, położnych, uprawnionych i samodzielnych techników dentystycznych oraz wykazy: aptek, szpitali, ubezpieczalni społecznych, ośrodków zdrowia, przychodni samodzielnych oraz centrali i filii Państwowej Szkoły Higieny, Poznań 1939.

\section{Zakończenie}

W dwudziestoleciu międzywojennym zawód farmaceutyczny w Poznaniu rozwijał się dynamicznie. W mieście mieszkało i pracowało coraz więcej farmaceutów, poczatkowo zatrudnionych głównie $\mathrm{w}$ aptekach ogólnodostępnych, ale z czasem znajdujących inne posady, np. w przemyśle. W latach 1923-1939 właściciele aptek na ogół posiadali przy nich mieszkania. Najwięcej aptekarzy mieszkało w Śródmieściu, jednak rozwój pozostałych dzielnic, tj. Jeżyc, Łazarza i Wildy, sprawił, że kolejne apteki powstawały także $w$ tych miejscach. $W$ dwudziestoleciu międzywojennym rozpoczęła się feminizacja zawodu farmaceuty.

\section{Wykaz źródeł:}

1. Książka adresowa miasta stołecznego Poznania; Telephone directory address-book (business and residential) z 1923, Zdigitalizowana księga jest dostępna jako źródło elektroniczne: http:/ / www. wbc.poznan.pl / dlibra / docmetadata?id=90630\&from=publication

2. Urzędowy spis lekarzy uprawnionych do wykonywania praktyki lekarskiej oraz aptek w Rzeczypospolitej Polskiej z 1924/1925 roku, Zdigitalizowana księga jest dostępna jako źródło elektroniczne: http: / / www.wbc.poznan.pl/ dlibra / docmetadata?id=102800\&from=publication

3. Książka adresowa miasta stołecznego Poznania; Telephone directory address-book (business and residential) z 1926 roku, Zdigitalizowana księga jest dostępna jako źródło elektroniczne: http: / / www. wbc.poznan.pl / dlibra / docmetadata?id=9725\&from=publication 
4. Spis abonentów sieci telefonicznej państwowej Okręgu Poznańskiej Dyrekcji Poczt i Telegrafów z 1926 roku. Zdigitalizowana księga jest dostępna jako źródło elektroniczne: http:/ / www.wbc.poznan.pl / dlibra / docmetadata?id $=403886 \&$ from $=$ publication

5. Urzędowy spis abonentów sieci telefonicznej Okręgu Dyrekcji Poczt i Telegrafów w Poznaniu 192627, Zdigitalizowana księga jest dostępna jako źródło elektroniczne: http:/ / www.wbc.poznan.pl/ dlibra $/$ docmetadata?id=335963\&from $=$ publication

6. Księga adresowa miasta stołecznego Poznania na rok 1933

7. Zdigitalizowana księga jest dostępna jako źródło elektroniczne: http:/ / www.wbc.poznan.pl/dlibra / docmetadata?id=403886\&from $=$ publication

8. Księga adresowa dla handlu-przemysłu-rzemiosła stoł. M. Poznania zawierająca alfabetyczny spis adresów wszelkich przedsiębiorstw handlowych przemysłowych oraz warsztatów rzemieślniczych z lat 1936/1937, Zdigitalizowana księga jest dostępna jako źródło elektroniczne: http:/ / www.wbc. poznan.pl / dlibra / docmetadata?id=110754\&from=publication

9. Urzędowy spis: lekarzy, lekarzy-dentystów, farmaceutów, felczerów, pielęgniarek, położnych, uprawnionych i samodzielnych techników dentystycznych oraz wykazy: aptek, szpitali, ubezpieczalni społecznych, ośrodków zdrowia, przychodni samodzielnych oraz centrali i filii Państwowej Szkoły Higieny, Cz. III. Farmaceuci z 1939 roku, Zdigitalizowana księga jest dostępna jako źródło elektroniczne: http: / / www.wbc.poznan.pl/ dlibra / docmetadata?id=101293\&from=publication

10. Spis abonentów telefonów m. st. Poznania z uwzględnieniem branż i zawodów z roku 1939, http:/ / www.wbc.poznan.pl/dlibra / docmetadata?id=105097\&from=publication

\section{Wykaz literatury:}

1. Filipski Łukasz, Socjotopografia Torunia w okresie międzywojennym w świetle analizy ksiag adresowych z 1923 i 1932 roku, „Rocznik Toruński”, 2016, s. 107.

2. Jaffe M., Księstwo Warszawskie i konstytucja municypalna 1806-1832 [w:] Poznań pod panowaniem pruskim, Poznań 2012, s. 123-124.

3. Kaniecki A., Rozwój gospodarczy Poznania, [w:] Poznań, Dzieje miasta woda pisane, Poznań 2004, s. 210560.

4. Kędelski M., Stosunki ludnościowe w latach 1815-1918, [w:] Dzieje Poznania, pod red. J. Topolskiego i L. Trzeciakowskiego, Warszawa-Poznań 1994, s. 262-263.

5. Materiały do historii aptek wielkopolskich, zestawił i opracował L. Kostrzeński, Poznań 1929.

6. Mrugalska-Banaszak M., Rozwój przestrzenny Poznania, [w:] Dzieje Poznania, t. 2, cz. 1, pod red. J. Topolskiego i L. Trzeciakowskiego, Warszawa-Poznań 1994, s. 817-825.

7. Ostrowska-Kębłowska Z., Architektura i budownictwo w latach 1793-1815, [w:] Dzieje Poznania, pod red. J. Topolskiego i L. Trzeciakowskiego, Warszawa-Poznań 1994, s. 102-110.

8. Skalski P., Pękacka-Falkowska K., Poznańscy studenci farmacji w latach 1920-1939: studium z zakresu historii społecznej, „Analecta: studia i materiały z dziejów nauki” 2016, nr 2 s. 139-195.

9. Wędzki J., Rozwój przestrzenny miasta w latach 1793-1815, [w:] Dzieje Poznania, pod red. J. Topolskiego i L. Trzeciakowskiego, Warszawa-Poznań 1994, s. 95-101.

10. Zielińska-Nowicka Agnieszka, Źródła do badania zagadnień demograficznych $i$ socjotopograficznych w XIX-wiecznym Toruniu, „Rocznik Toruński”, 2008, s. 162.

11. Zdrojewska-Nowak Marta, Produkty lecznicze i wyroby medyczne reklamowane na łamach "Gazety Toruńskiej” (1867-1921). Wybrane przykłady, „Rocznik Toruński” 2016, s. 205-224; http:// yadda.icm.edu. $\mathrm{pl} /$ yadda/element/bwmeta1.element.desklight-348da56a-e4cb-40a6-9557-e88a8a868a19? q=bwmeta1.element.cejsh-84fc94c4-6f45-4037-a321-8e1dbcda8ff9;7\&qt=CHILDREN-STATELESS (dostęp: 06.06.2018). Na podstawie pracy magisterskiej obronionej na Wydziale Farmaceutycznym UMP. 